\title{
Is benevolence the pinnacle of an employment relations trust hierarchy?
}

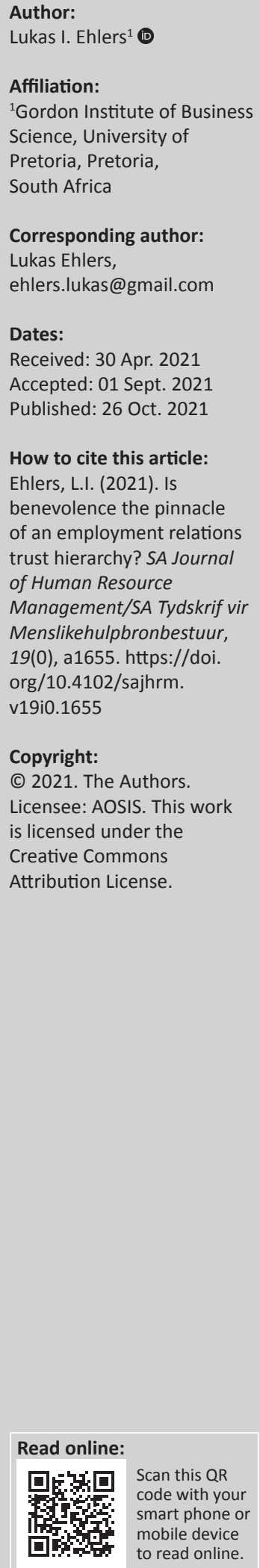

Background: Employment relations trust (ERT) is related to compliance, fairness, good faith and benevolence in such relations. Benevolence is not a legal obligation in employment relations and will typically be displayed voluntarily. Gaps in the literature suggested a need for a valid and reliable theory of employment relations benevolence and its relationship with trust in such relations.

Aim: This study was undertaken to investigate the relationship between benevolence and the development of trust in employment relations.

Setting: The study was undertaken in the Gauteng province of the Republic of South Africa.

Methods: An exploratory quantitative research method was implemented to test two hypotheses emanating from a literature review. A questionnaire survey facilitated the collection of data from 83 purposefully sampled voluntary respondents, who were ordinary employees, managers and academics. Statistical analysis was done to test the validity of two hypotheses.

Results: Employment relations trust can be expected to develop through four distinct, overlapping and relatively predictable sequential stages, namely compliance, fairness, good faith and benevolence. Benevolence can be assumed to be the last stage in this development process.

Conclusion: Benevolence can be regarded as the erratic pinnacle of a four levelled theoretical hierarchy of ERT. Benevolence can occur before, during or after displays of compliance, fairness or good faith in employment relations.

Contribution: This theory of ERT provides valid and reliable foundations for dealing with and researching a variety of aspects related to benevolence and trust in employment relations.

Keywords: employment; relations; trust; development; hierarchy; fairness; good faith; benevolence.

\section{Introduction}

Trust is the willingness of an entity (trustor) to rely on another entity (trustee) to behave in an agreed upon or expected manner. Trust is widely regarded as a universal foundation for harmonious and productive human relations in societies, organisations, families and close personal relationships (Covey, 2006; Firmansyah, Amelia, Jamil, \& Minza, 2019; McKnight \& Chervany, 2014). Mutual respect and trust in most societal relations, including employment relations, can be confidently expected to facilitate the achievement of mutually beneficial relationship objectives (Kushitor et al., 2018).

Fawcett, Fawcett and Jin (2017) concluded that academic definitions of benevolence are divergent, and that the notion of benevolence is often ignored in trust-related research studies. Nonetheless, findings from numerous studies confirmed the virtues of trust and benevolence in social relationships. Mbuma (2019) concluded that trust and benevolence can be confidently assumed to be positive and desirable social conditions in supervisory relationships. Another study confirmed that trustors typically prefer being friends with more benevolent people in their social circles (Firmansyah et al., 2019). Bell and McKague (2017) found that positive perceptions of benevolence resulted from positive value-maximising experiences in economic exchanges. Hubbard, Harbaugh, Srivasta, Degras and Mayr (2016) found that benevolence and true concern are more evident during the exchanges of older adults in their social relationships.

These findings strongly suggest that trust and benevolence are desirable social phenomena that are also desirable in employment relations. Higher levels of trust and benevolence can be expected 
to be more prevalent in mature employment relationship that evolved through certain trust developing stages. The views of numerous authors suggested that employment relations trust (ERT) may develop in a sequential hierarchal order, along the same lines as Maslow's hierarchy of needs (Covey, 2006; Ehlers, 2020; Maslow, 1943; Savolainen \& Ikonen, 2016; Schilke \& Cook, 2013).

A focussed literature search resulted in the location of numerous publications related to trust and benevolence in organisational contexts. However, the search failed to locate a recent publication that specifically dealt with integrated theoretical models of trust and benevolence in the context of employment relations.

\section{Research objectives}

This study aimed to investigate and determine the stages through which ERT develops and the specific nature and role of employment relations benevolence (ERB) in this development process. The achievement of these objectives required that the validity of two alternative hypotheses be tested:

H0: There is no evidence to support the validity of alternative hypotheses.

H1: Employment relations trust develops through distinctive sequential stages.

H2: Benevolence is the pinnacle of a theoretical hierarchy of employment relations trust.

\section{Overview}

The remainder of this article contains a literature review, a discussion of the quantitative research methodology that was adopted in this study, a discussion of findings and an overview of the limitations and recommendations of the study. Specific conclusions and recommendations are discussed in the section preceding the concluding remarks.

\section{Literature review}

\section{Trust in labour relationships}

There are no laws that specifically order and protect high levels of trust in any societal, organisational or employment relationships. However, trust is generally regarded as the foundation of such relationships despite the numerous philosophical, legal, political, economic, sociological, psychological, moral and ethical variables that apply. There are numerous definitions, explanations and classifications of various forms of trust that can manifest in many different social contexts (Covey, 2006; McKnight \& Chervany, 2014; Stern \& Coleman, 2020). For the purpose of this study, trust will be defined as the willingness of a vulnerable trustor (e.g. an employee) to rely on a trustee (e.g. an employer or employer representative) to behave in an agreed upon or expected manner (Starnes, Truhon, \& McCarthy, 2016).

Trust can be regarded as the backbone of employment relations. Numerous studies concluded that organisational, supervisory relationship as well as ERT levels are positively related to a wide variety of desirable organisational and employment relations outcomes (Robbins \& Judge, 2017; Searle \& Skinner, 2011). Employment relations trust levels were also found to be positively related to positive perceptions of compliance, fairness and good faith in supervisory relationships, as well as positive perceptions of employment relations satisfaction and employment relations quality (Ehlers, 2020; Krot \& Lewicka, 2012).

Employers use a wide variety of criteria to assess the trustworthiness of their employees and can apply disciplinary procedures when breaches of trust are suspected (Viviers \& Smit, 2015). However, most employees will assess the trustworthiness of their supervisors by judging their abilities (skills, competencies, means), benevolence (willingness to create benefits for subordinate) and integrity (predictability and reliability). An employee will not typically anticipate exploitation by an employer when employment relationship trust levels are perceived to be high and vice versa (Mayer, Schoorman, \& Davis, 2007). Subordinate expectations, experiences and outcomes of previous trust exchanges will usually result in revised positive or negative perceptions of supervisor trustworthiness in future exchanges (Robbins, Judge, \& Campbell, 2017; Starnes et al., 2016). Low trust levels or distrust often result in job dissatisfaction, stress, complaints, formal grievances and other forms of employment relations conflict (Ehlers, 2020).

Most employees in a trusting, positive or euphoric state of mind will typically not expect or fear malevolence, exploitation or withholding of benefits by an employer or employer representative. Accordingly, they may subtly or openly expect and welcome displays of benevolence by a trustee. However, employees in distrusting, negative or distressed states could subtly or openly suspect and fear malevolence, exploitation or withholding of benefits by a trustee employer or employer representative. Employee expectations of malevolence will make them doubt the sincerity of any sudden displays of 'benevolence' by their employers. The same behaviour forms can be expected to apply when an employer adopts the role of trustor and an employee adopts the role of trustee in employment relationships (Kushitor et al., 2018; Mayer et al., 2007; Robbins \& Judge, 2017).

Table 1 contains definitions and criteria for analysing levels of trust, compliance, fairness and good faith in employment relations. The levels of trust, compliance, fairness and good faith in an employment relationship have been objectively estimated by recording the number of times that a characteristic of the condition manifests in an employment relationship. For example, a very low level of fairness can be assumed if at least one of five basic criteria for fairness is demonstrated in an employment relationship, and a very high level of fairness can be assumed if all five of the basic criteria for fairness are demonstrated in employment relationships (Ehlers, 2020). 
TABLE 1: Compliance, fairness, good faith and trust in employment relations.

\begin{tabular}{ll}
\hline Definitions & Criteria \\
\hline Trust & Trust is evident when parties are: \\
Relationship partners are willing to risk & 1. Convinced \\
vulnerability by relying on each other to & 2. Devoted \\
behave in an expected manner. & 3. Tolerant \\
& 4. Supportive \\
& 5. Loyal \\
Compliance & Compliance is evident when parties are: \\
Relationship partners comply with & 1. Constitutional \\
formal relationship guidelines in all & 2. Legal \\
their relationship exchanges & 3. Contractual \\
& 4. Directional \\
& 5. Procedural \\
Fairness & Fairness is evident when parties are: \\
Relationship partners treat each other & 1. Informed \\
in an even-handed manner in all & 2. Objective \\
relationship exchanges & 3. Equitable \\
& 4. Consistent \\
Good faith & 5. Reciprocal \\
Relationship partners sincerely promote & Good faith is evident when parties are: \\
mutual relationship benefits in all & 2. Sincere \\
relationship exchanges & 3. Respectful \\
& 4. Constructive \\
& 5. Considerate
\end{tabular}

Source: Ehlers, L.I. (2020). Trust and perceptions of compliance, fairness and good faith in primary labour relationships. South African Journal of Economic and Management Sciences, 23(1), a3353. https://doi.org/10.4102/sajems.v23i1.3353

Several authors identified different stages in the development of trust in different contexts. Covey (2006) believed that trust is a choice that develops through six consecutive waves, namely credibility, behaviour, organisational trust, market trust and societal trust. Schilke and Cook (2013) found that organisational trust develops through four stages, namely initiation, negotiation, formation and operation. Savolainen and Ikonen (2016) identified initiation, opening and progress as the three stages through which trust develops in teams. Ehlers (2020) suggested that ERT can be expected to develop through at least three stages, namely compliance, fairness and good faith. There is thus ample evidence to assume that trust develops through a few stages.

\section{Benevolence in employment relations}

Empowered people strive to inspire and empower others to look beyond self-interest and make differences and contributions in their workplace and societies. They are spiritually minded and typically display benevolence, generativity, humanism, integrity, justice, mutuality, receptivity, respect and responsibility in their relationships with other people (Sarkar, 2017). The socalled golden rule (Do unto others as you would have them do unto you) has strong spiritual roots and is commonly revered in most mainstream religions. An alternative version of the 'golden rule' (Do not do unto others as you would not have them do unto you) is also often used as a guideline for moral and ethically sound exchanges in societal and organisational exchanges (Rakhshani, 2017; Simoncelli, 2020). Other variations suggest that all human beings should only display behaviours that they want all other beings to display towards all other living beings (Dalai Lama, 2011; Einstein, 1935; Kant, 1785; Schweitzer, 1987).

Countless variations of the 'golden rule' appear to have been conceived as an umbrella term for promoting certain forms of humane reciprocity in the exchanges between people in some or other social structure (Rakhshani, 2017). It thus seems that obedience to a 'golden rule' in employment relations can facilitate intentional displays of trust inspiring behaviours such as compliance, fairness and good faith by employers or employees in such relations. Many authors confirm that such behaviour often results in positive perceptions of the quality of human exchanges in employment relations. Humane reciprocity appears to be a desirable social condition in good quality employment relationships (Ehlers, 2020; Sarkar, 2017; Simoncelli, 2020).

Findings from recent studies strongly suggest that benevolence, as in the case with compliance, fairness and good faith, can also be expected to have a positive effect on organisational relations (Sree \& Gunaseelan, 2018; Starnes et al., 2016). Benevolence can be defined as an intentional willingness to bring about some or other benefits without any expectation to receive anything in return (Tullberg, 2012). It should be noted that beneficence occurs when a benefactor acts to the benefit of a beneficiary, with or without kind or charitable intentions, and that benevolence occurs when a benefactor acts to the benefit of a beneficiary with kind or charitable intentions (Beauchamp, 2016; Mayer et al., 2007). Mere beneficence is thus not kindness or charity.

Benevolent behaviours have strong ethical, moral and spiritual foundations. Benevolence is not a reciprocated action or obligation and often takes the form of an unpredicted, random or erratic display of goodwill or kindness. Benevolent acts can also follow some or other awareness of related or unrelated inspiring benevolent behaviours that occurr in the environment of a benefactor or beneficiary (Tullberg, 2012). Nonetheless, benevolent benefactors will never have an egocentric motive when any form of unselfish, good, kind and charitable behaviours is displayed towards a beneficiary (Capelletti et al., 2010).

Positive perceptions of benevolence in supervisory relationships can inspire and create stronger emotional bonds between supervisors and subordinates (Xin Tan \& Dahlia, 2016). Benevolent leadership refers to 'a state of individualised care' in which organisational leaders allow their followers to rectify mistakes and avoid dishonour, amongst others (Sree \& Gunaseelan, 2018). Benevolent leaders will typically refrain from exploitative behaviours aimed at the deliberate promotion of self-interest, profit or personal gain at the expense of their followers (Zapata, Olsen, \& Martins, 2013). Displays of benevolence by representatives of an employer, or leaders, often confirm that the employer is generally a trustworthy entity who is willing to act in the best interest of its employees or followers (Shanock \& Eisenberger, 2006). Likewise, employee displays of benevolence and integrity in supervisory relationships were found to engender feelings of obligation and trust in their direct supervisors (Zapata et al., 2013).

However, the absence of benevolence has been linked to higher levels of malevolent workplace behaviours such as exploiting employees or employers, abusing confidential information for personal gain, harassment, stress or even workplace violence (Cappelletti, Khalla, Noguera, Scouarnec, \& 
Voynnet Fourboul, 2010). Employee perceptions of malevolence, or non-benevolence, in their workplaces were found to be related to negative or destructive feelings about themselves or their work environments (Xin Tan \& Dahlia, 2016). However, Law (2013) found that the encouragement of forgiveness in supervisory relationships is related to more positive perceptions of job satisfaction and diminished quit intentions amongst subordinates.

No specific definitions or discussions of 'Employment relations benevolence $(\mathrm{ERB})^{\prime}$ were found in the literature. However, it appears logical to assume that ERB will refer to any intended displays of benevolence by leaders or followers during any stage of an employment relationship (Zapata et al., 2013). It can be confidently assumed that all forms or displays of ERB will meet all criteria for compliance, fairness and good faith in all forms of employment relations (Cappelletti et al., 2010: Ehlers, 2020). Alleged displays of ERB that are in any way noncompliant, unfair or in bad faith could amount to some or other form of malevolence. Such veiled ERB should consequently be frowned upon (DiMatteo, Bird, \& Colquitt, 2011; Viviers \& Smit, 2014: Xin Tan \& Dahlia, 2016).

A minimum level of benevolence may be present in an employment relationship when at least one of five basic criteria for benevolence are met. Conversely, it can be argued that a very near maximum level of ERT may be present if all five criteria are met. Table 2 provides an overview of the five basic criteria for benevolence in employment relations.

\section{Hierarchy theory}

Smuts (1926) likened mountains to ladders of life or social hierarchies that exist to fulfil a purpose that originates at the peak of the hierarchy (Smuts, 1926). Many, if not most, natural and social phenomena display some or other hierarchical quality. Therefore, hierarchy theory can be effectively applied to answer research questions in a wide variety of scientific disciplines (Wu, 2013). The theories of Darwin (1859) and Smuts (1926) strongly suggest that humans, animals and plants evolve through a set of sequential hierarchal evolutionary stages before becoming a fulfilled whole. In the same vein, hierarchy theory proposes that the smaller related parts of whole entities can be structured into related categories that relate to each other in some form of distinctive pattern.

TABLE 2: Employment relations benevolence.

\begin{tabular}{|c|c|}
\hline Definition & Criteria \\
\hline $\begin{array}{l}\text { Benevolence } \\
\text { Any intended benevolent } \\
\text { behaviour form in an } \\
\text { employment relationship } \\
\text { that meets all criteria for } \\
\text { compliance, fairness and } \\
\text { good faith in employment } \\
\text { relations. }\end{array}$ & $\begin{array}{l}\text { Benevolence is evident when parties display: } \\
\text { 1. Kindness (displaying tolerance, acceptance and/or } \\
\text { forgiveness towards other people or entities) } \\
\text { 2. Charity (creating any form of benefit for other people } \\
\text { or entities without expecting anything in return) } \\
\text { 3. Goodwill (displaying unconditional friendliness } \\
\text { towards other people or entities) } \\
\text { 4. Unselfishness (not seeking or expecting any gain } \\
\text { whatsoever from displays of benevolence towards } \\
\text { other people or entities) } \\
\text { 5. Sacrifice (forsaking something that holds personal } \\
\text { value for the sake of other people or entities) }\end{array}$ \\
\hline
\end{tabular}

Source: Cappelletti et al. (2010); Dietz and Hartog (2015); Ehlers (2020); Krot and Lewicka (2012); Ogunyemi (2014); Mayer et al. (2007); Xin Tan and Dahlia (2016); Zapata et al. (2013).
Numerous scientific fields rely on simpler and complex derivatives of hierarchy theory to explain the nature of phenomena (Thomsen, 2020; Wu, 2013). Savolainen and Ikonen (2016) demonstrated the applicability of hierarchy theory to trust development when they likened the development of trust in teams to the seeding (initiation), sprouting (opening) and growing (progress) to the hierarchal growth process that occurs in a tree.

\section{Maslow's hierarchy of human needs}

Maslow's hierarchy of needs is probably the most wellknown example of a theoretical representation of a social hierarchy. This theory is a mainstay in many fields of psychology education, research and practice, and the content of related studies have provided excellent guidelines on the application of hierarchy theory in social sciences (Ghatak \& Singh, 2019). Maslow (1943) described the five categories in his original hierarchy of human needs as follows:

1. Fifth level - Self-actualisation: People at this level are reality centred, cognitive of their own unique potential and able to differentiate between truth and falsehoods. They typically strive to live up to their own definition of material and/or spiritual fulfilment.

2. Fourth level - Esteem: People at this level strive to satisfy their need for esteem by experiencing feelings of competence, recognition and achievement satisfaction.

3. Third level - Love and belonging: People at this level strive to satisfy their need to bond with family, friends, work colleagues and other acquaintances.

4. Second level - Safety needs: People at this level strive to satisfy their needs for security, order and stability to ensure their physical survival.

5. First level (lowest) - Physiological needs: People at this level strive to satisfy their basic existence needs, namely food, water, sleep, sex, steadiness and excretion.

Most people will focus their attention and effort to secondlevel needs after satisfying most of their first level needs. The same applies for needs at the third, fourth and fifth levels. However, Maslow (1943) observed that some people elect to spend very little or no energy on achievement of needs in the first four levels in order to devote more time and energy to fulfilling their self-actualisation needs. These behaviours are not easily predicted and can subsequently be described as elusive, random and/or erratic. Maslow's expanded hierarchy of needs (1971) included two additional higher-order categories. Cognitive needs (knowledge and understanding, curiosity, exploration, need for meaning and predictability) replaced self-actualisation as the fifth hierarchical level, whilst aesthetic needs (appreciation and search for beauty, balance, form, etc.) were introduced as the sixth level. Self-actualisation became the seventh and highest category in the expanded hierarchy. The expanded higher categories allowed for more effective analysis of relationships amongst religious, spiritual and psychological needs and behaviours of human beings (Desmet \& Fokkinga, 2020). 


\section{Typical characteristics of theoretical hierarchies}

Analysis of the information under Sections 2.3 and 2.4 strongly suggests that most theoretical hierarchies will typically share at least seven characteristics. These are:

1. Theoretical hierarchies are distinctive ordered wholes.

2. Theoretical hierarchies have distinctive central themes.

3. Theoretical hierarchies have distinctive lowest categories.

4. Theoretical hierarchies have distinctive middle categories.

5. Theoretical hierarchies have distinctive highest categories.

6. Most people will satisfy most or all conditions in a lower category before attempting to satisfy any conditions in an adjacent higher category.

7. Some energy expending entities (e.g. people) may choose to focus all or most of their efforts on satisfying conditions in the highest category without attempting to satisfy all or most conditions in lower categories.

\section{Research methodology}

A quantitative research methodology was adopted to explore and develop a new theory. Gay and Weaver (2011) and Snow and Thomas (1994) recommended that the following activities be performed during theory development: (1) identifying key constructs, concepts and variables, (2) describing relationships between phenomena and theoretical rationales,

(3) determining boundary conditions of the theory, (4) developing a valid and reliable measure of key concepts and constructs, (5) establishing the nature of relationships between variables and (6) testing theory validity through critical experimentation and hypothesis testing. This study was concluded after determining and describing boundary conditions of the theory and recommending further development and validation requirements.

Even though larger samples are preferred in exploratory studies, many researchers agree that the integration of findings from literature reviews and statistical analysis of data from relatively small samples can result in trustworthy research findings (Cresswell, 2014; Cozby \& Bates, 2015; Trotsuk, 2016). The following methodology was adopted in this study:

1. Study objectives, hypotheses and research methodology were defined.

2. Ethical clearance to conduct the study for purposes of this article was obtained from the Gordon Institute of Business Science (GIBS) of the University of Pretoria during August 2018. All guidelines for conducting ethical research under the auspices of GIBS were adhered to in all phases of this study.

3. A literature review on the nature of trust and benevolence in employment relations, as well as the nature of hierarchies was undertaken.

4. A survey questionnaire was developed in accordance with guidelines in Cozby and Bates (2015) and Cresswell (2014). The questionnaire included two biographical items relating to age and gender and 20 items dealing with relationships between different levels of trust and different levels of compliance, fairness, good faith and benevolence in employment relationships.

5. Questionnaire items and response options were specifically aimed at collecting data that was narrowly aligned with the research questions and hypotheses. This was done to ensure higher than adequate levels of questionnaire validity (Ehlers, 2020; Trotsuk, 2016).

6. Ten volunteers were requested to complete the questionnaire survey. They expressed positive sentiments and feedback after completing the questionnaire. A Cronbach's alpha coefficient of 0.79 confirmed that the reliability and consistency of the questionnaire were relatively high (Salkind, 2014).

7. Two separate datasets were collected. Random and snowball sampling methods were used to collect the first dataset from 50 informed and consenting people who were employed in non-managerial positions. They all resided in the Gauteng province of the Republic of South Africa (RSA). The second dataset was collected electronically, using an online survey on the Google Forms website. Invitations to participate in the study was then sent to 75 HRM and LR academics and managers across the RSA. Thirty three invitees completed the electronic survey within 1 month after being invited.

8. The total sample size of 83 was assumed to be adequate for purposes of the study (Cresswell, 2014; Salkind, 2014; Trotsuk, 2016). There were 43 males and 40 females in the sample. The average age of sample members was 30.88 . The age of 46 respondents were between 25 and 40 years, whilst 37 respondents were older than 40 years.

9. Finally, data were captured in an electronic database, and statistical analysis procedures were implemented.

\section{Discussion of findings Validity of $\mathbf{H} 1$}

$\mathrm{H} 0$ was rejected in favour of $\mathrm{H} 1$.

It was confidently concluded that ERT will typically develop through four distinct and predictable sequential stages in most employment relationships. However, less frequent random displays of fairness, good faith and benevolence can be confidently expected to occur from the onset of the relationship. Random displays of fairness will be more typical than random displays of good faith, which will in turn be more typical than random displays of benevolence in employment relations. The following findings supported these conclusions:

1. Compliance, fairness, good faith and benevolence (CFGB) can be assumed to be four typical characteristics of ERT. Mean scores indicate that some or other level of compliance, fairness, good faith and benevolence can be confidently expected to be present in employment relations, irrespective of the levels of ERT. Figure 1 reflects perceived levels of CFGB at different levels of trust in employment relations: 


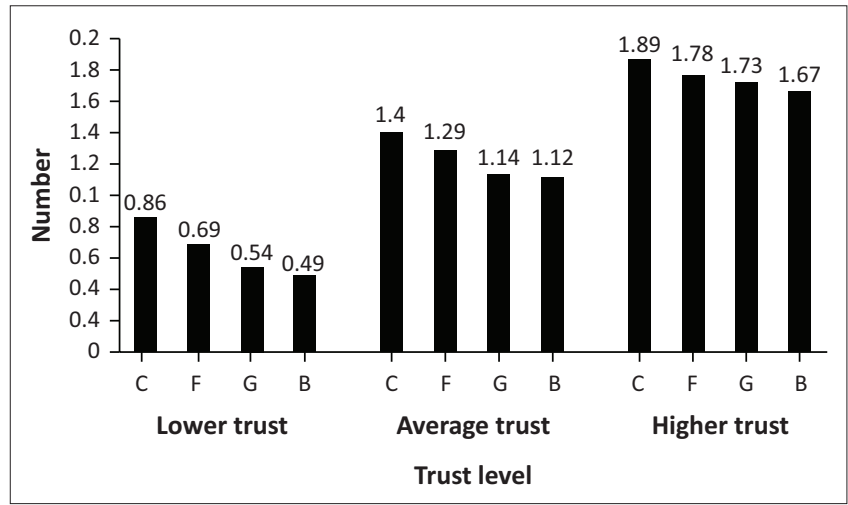

FIGURE 1: Compliance, fairness, good faith and benevolence at different trust levels.

1. At face value, the contents of Figure 1 confirm that the respective mean levels of CFGB levels appear to increase in accordance with increases in the levels of trust in employment relations. The following specific observations were made:

a. Respondents perceived far below average levels of CFGB in employment relations where lower levels of ERT reside ( $\bar{x}$ below 1$)$.

b. Respondents perceived average levels of CFGB in employment relations where average levels of ERT reside ( $\bar{x}$ between 1 and 1.5 ).

c. Respondents perceived above average levels of CFGB in employment relations where higher levels of ERT reside ( $\bar{x}$ above 1.5$)$.

2. The perceived general levels of CFGB in employment relations are positively related to the levels of ERT. All Pearson correlation coefficients were statistically significant at $p=0.00(\mathrm{C}-\mathrm{T}=0.665 ; \mathrm{F}-\mathrm{T}=0.689$; $\mathrm{G}-\mathrm{T}=0.695 ; \mathrm{B}-\mathrm{T}=0.663)$.

3. The investigation of differences between sample groups with different demographic characteristics fell outside of the scope of this study. However, it is worth noting that Mann-Whitney $U$ test results confirmed that managers and academics held more positive perceptions on the levels of fairness, good faith and benevolence at different ERT levels. This could be the result of managers and academics being less likely to experience controlled, restrictive or even abusive employment relations practices (ILO, 2020; Priesemuth, 2020). Nonetheless, both sample groups perceived a positive relationship between increases in CFGB and ERT. Table 3 reflects the perceived levels of CFGB at different levels of ERT and the statistical differences between perceptions of sample groups that are employed at different organisational levels.

1. Data analysis confirmed that ERT could be confidently expected to develop through four sequential stages, namely:

a. First stage: Compliance (mean of ranks $=1.43$, logically rounded to 1 );

b. Second stage: Fairness (mean $=1.93$, logically rounded to 2);

c. Third stage: Good faith (mean $=2.76$, logically rounded to 3); and

d. Fourth stage: Benevolence (mean $=3.88$, logically rounded to 4 ).
TABLE 3: Perceived compliance, fairness, good faith and benevolence levels: Employment groups

\begin{tabular}{llccc}
\hline Variable & $\begin{array}{l}\text { Mann-Whitney U test } \\
\text { * Statistically significant at } \boldsymbol{p}<\mathbf{0 . 0 5}\end{array}$ & $\begin{array}{c}\text { Lower } \\
\text { trust }\end{array}$ & $\begin{array}{c}\text { Average } \\
\text { trust }\end{array}$ & $\begin{array}{c}\text { Higher } \\
\text { trust }\end{array}$ \\
\hline Compliance & Mean score & 0.86 & 1.4 & 1.89 \\
& 1. General employees & 0.82 & 1.2 & 1.84 \\
& 2. Managers and academics & 0.91 & 1.7 & 1.97 \\
& Significance of differences (1-2) & 0.450 & $0.000^{*}$ & 0.065 \\
Fairness & Mean score & 0.69 & 1.29 & 1.78 \\
& 1. General employees & 0.66 & 1.12 & 1.66 \\
& 2. Managers and academics & 0.73 & 1.55 & 1.97 \\
& Significance of differences (1-2) & 0.669 & $0.000 *$ & $0.001 *$ \\
Good faith & Mean score & 0.54 & 1.14 & 1.73 \\
& 1. General employees & 0.54 & 0.94 & 1.62 \\
& 2. Managers and academics & 0.55 & 1.45 & 1.91 \\
& Significance of differences (1-2) & 0.961 & $0.000 *$ & $0.004 *$ \\
Benevolence & Mean score & 0.49 & 1.12 & 1.67 \\
& 1. General employees & 0.54 & 0.92 & 1.52 \\
& 2. Managers and academics & 0.42 & 1.42 & 1.91 \\
& Significance of differences (1-2) & 0.305 & $0.000 *$ & $0.000 *$ \\
\hline
\end{tabular}

2. Each of the four stages of ERT can be expected to have distinct onset, development and maturity phases. However, these phases should be regarded as dynamic phenomena that are relatively unpredictable. Prediction of the characteristics and duration of these phases will be influenced by numerous variables in and around the employment relationship in which it manifests.

3. Unique overlaps may exist between the respective stages in the development of ERT. The nature and duration of overlaps could vary in accordance with unique relationship environments and variables.

\section{Validity of $\mathbf{H} \mathbf{2}$}

$\mathrm{H} 0$ was rejected in favour of $\mathrm{H} 2$.

Benevolence can be regarded as the pinnacle of a theoretical hierarchy of ERT if it is recognised that manifestations of benevolence in ER are relatively predictable and often unpredictable, as is the case of self-actualisation in the Maslow hierarchy of needs. The characteristics of ERT development are narrowly aligned with the characteristics of theoretical hierarchies (see Table 3). The following specific findings support these conclusions:

1. Benevolence can be described as a moral, ethical or spiritual value and/or need that gives rise to mutual benefit, equality and goodwill amongst human beings. Benevolence is not a legal requirement in employment relations within free market economies. Moreover, it was learnt that related concepts such as 'workplace benevolence' and 'leadership benevolence' often refer to behaviours that are more typical of fairness and good faith in employment relations. Nonetheless, benevolence is distinctly different from fairness and good faith, and displays of fairness and good faith in employment relations should not be confused with displays of benevolence in such relations (Beauchamp, 2016; Capelletti et al., 2010; Sree \& Gunaseelan, 2018; Xin Tan \& Dahlia, 2016; Zapata et al., 2013). Literature review and statistical analysis findings confirmed that true 
benevolence can be confidently expected to occur in employment relations, irrespective of the levels of trust that reside in such relations.

2. Statistical analysis findings confirmed that benevolence can be confidently regarded as the fourth stage in the development of ERT (see confirming data under 4.1.v). However, as with the case of self-actualisation in the Maslow hierarchy (Maslow, 1943), benevolence can be confidently expected to appear randomly before, during or after any or all conditions related to compliance, fairness and good faith were met (Beauchamp, 2016; Capelletti et al., 2010; Dietz \& Hartog, 2015; Sree \& Gunaseelan, 2018; Xin Tan \& Dahlia, 2016; Zapata et al., 2013)

3. The characteristics of ERT are narrowly aligned with the seven characteristics of theoretical hierarchies. Table 4 compares these general criteria to the qualities of ERT.

\section{Integrated findings}

\section{Definitions and characteristics of employment relations trust theory}

The characteristics of ERT and CFGB were comprehensively described in Tables 1 and 2. There are distinct differences between the characteristics of these phenomena. Displays of compliance, fairness or good faith in employment relations typically requires mutual displays of some form of reciprocal beneficence. However, such forms of beneficence do not constitute displays of some or other forms of ERB.

\section{Boundary conditions}

The content of the literature review and general findings of this study strongly suggested that the following theoretical assertions be accepted as boundary conditions for further investigation or application of ERT theory:

1. ERT is a whole construct that encapsulates four distinctive categories or overlapping stages through which trust is developed, namely compliance, fairness, good faith and benevolence. Each of the four categories or stages can be related to lower or higher levels of ERT, earlier or later

TABLE 4: Characteristics of theoretical hierarchies.

\begin{tabular}{|c|c|}
\hline General characteristics & ERT characteristics \\
\hline $\begin{array}{l}\text { 1. Theoretical hierarchies are distinctive } \\
\text { ordered wholes. }\end{array}$ & $\begin{array}{l}\text { The development of ERT can be } \\
\text { conceptualised as a distinctive ordered } \\
\text { whole. }\end{array}$ \\
\hline $\begin{array}{l}\text { 2. Theoretical hierarchies have distinctive } \\
\text { central themes. }\end{array}$ & ERT is the distinct central theme. \\
\hline $\begin{array}{l}\text { 3. Theoretical hierarchies have distinctive } \\
\text { lowest categories. }\end{array}$ & Compliance is the lowest category. \\
\hline $\begin{array}{l}\text { 4. Theoretical hierarchies have distinctive } \\
\text { middle categories. }\end{array}$ & $\begin{array}{l}\text { Fairness is the second middle category. } \\
\text { Good faith is the third middle category. }\end{array}$ \\
\hline $\begin{array}{l}\text { 5. Theoretical hierarchies have distinctive } \\
\text { highest categories. }\end{array}$ & Benevolence is the highest category \\
\hline $\begin{array}{l}\text { 6. Most people will satisfy most or all the } \\
\text { conditions in a lower category before } \\
\text { attempting to satisfy any conditions in } \\
\text { an adjacent higher category. }\end{array}$ & $\begin{array}{l}\text { ERT develops through predictable, yet } \\
\text { overlapping stages of compliance, } \\
\text { fairness, good faith and benevolence. } \\
\text { Progress to a next level may depend on } \\
\text { satisfaction of needs in a previous level. }\end{array}$ \\
\hline $\begin{array}{l}\text { 7. Some people may choose to focus all } \\
\text { or most of their efforts on satisfying } \\
\text { conditions in the highest category } \\
\text { without attempting to satisfy all or } \\
\text { most conditions in lower categories. }\end{array}$ & $\begin{array}{l}\text { Displays of benevolence may occur } \\
\text { before during or after the first three } \\
\text { stages in the development of ERT. }\end{array}$ \\
\hline
\end{tabular}

ERT, employment relations trust. stages of employment relationships, less or more legal regulation and less or more self-interest protection.

2. Trust is the central theme that rules behaviour in the whole. ERT can be confidently expected to develop in four relatively predictable stages. However, atypical random manifestations of fairness, good faith, or benevolence can be expected to occur before, during or after establishing the parameters for compliance in employment relations.

3. Compliance is the first category, or development stage, in the hierarchy of ERT. Criteria for compliance with the constitution, common law contracting principles, statutory laws, policies and procedures are clearly defined and required in formally documented employment relations guidelines. They are typically fulfilled in such relationships. Most employees and employers will typically focus on meeting all or most of the requirements for compliance in ER before attempting to meet one or more requirement of fairness in ER. Compliance can be described as the primary or outlining feature of ERT. There can be no employment relationship without proper definition of rights and duties of the parties to the relationship.

4. Fairness is the second category or development stage in the hierarchy of ERT. Awareness, objectivity, equity, consistency and reciprocity are basic criteria for fairness are mostly clearly defined and required in many formally documented employment relations guidelines. They are usually fulfilled in such relationships. Most employees and employers will typically focus on meeting all or most of the requirements for fairness in ER before attempting to meet one or more requirement of good faith in ER. Fairness can be described as the secondary or stabilising feature of ERT that promotes compliance, harmony and stability in employment relations. Random displays of fairness may also occur alongside displays of compliance at the onset and very early stages of an ER trust relationship.

5. Good faith is the third category, or development stage, in the hierarchy of ERT. Interest, sincerity, respect, constructivity and consideration are basic criteria for good faith that are typically implicated in labour laws and related employment relations documents. They are sometimes fulfilled in such relationships. Most employees and employers will typically focus on meeting all or most of the requirements for good faith in ER before attempting to meet one or more requirement of benevolence in ER. Mutually beneficial employment relationship exchanges can be described as a tertiary or enhancing feature of ERT that typically builds on compliance and fairness to promote harmonious, stable and productive employment relations. Random displays of good faith may also occur alongside displays of compliance and fairness at the onset and early stages of an ER trust relationship.

6. Benevolence is the fourth category or final development stage in the hierarchy of ERT. Kindness, goodwill, charity, unselfishness and sacrifice are five basic criteria for benevolence in ER. These characteristics are not defined, implicated or required in any formally documented employment relations guidelines and can be described as a spiritually inspired employment 
relations phenomenon. Demonstrations of benevolence in ER are also less predictable than demonstrations of compliance, fairness and good faith. Nonetheless, sequential manifestations of these conditions could be confidently expected to pave the way for benevolent ER behaviours. Benevolent employment relationship exchange can be regarded as quaternary or indulging feature of ERT that will typically follow earlier displays of compliance, fairness and good faith in an ER. Benevolence can be confidently expected to promote harmonious, stable, productive and fulfilling employment relationships. Random displays of benevolence can occur alongside displays of compliance, fairness and good faith before, during or after all the stages of ERT has been fulfilled.

\section{Sequential development of employment relations trust}

Figure 2 illustrates the four relatively predictable sequential stages through which ERT typically develops and the less predictable, elusive, erratic, non-sequential random occurrences of the phenomena that can occur in employment relations. The solid-coloured blocks to the right represent predictable sequential sequences, and the varying densities to the left represent the random occurrences of latter stages in earlier stages of ERT development. All descriptions that were listed under 4.3.1 and all boundary conditions that were described under 4.3.2 are applicable to the content of Figure 2.

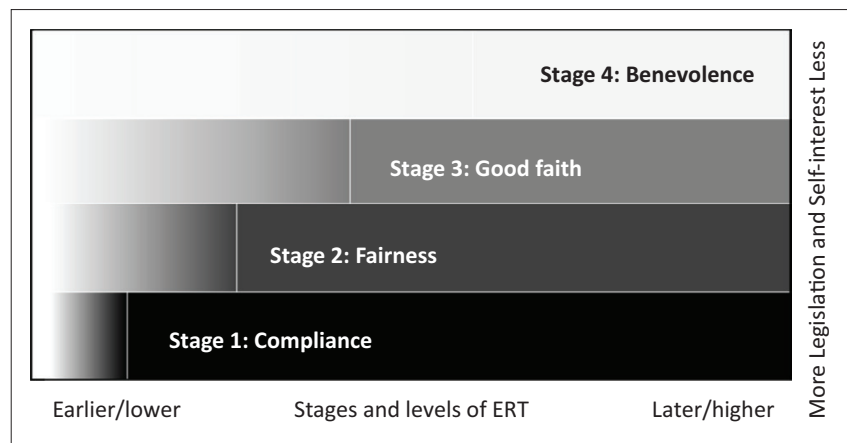

FIGURE 2: Sequential development of employment relations trust.

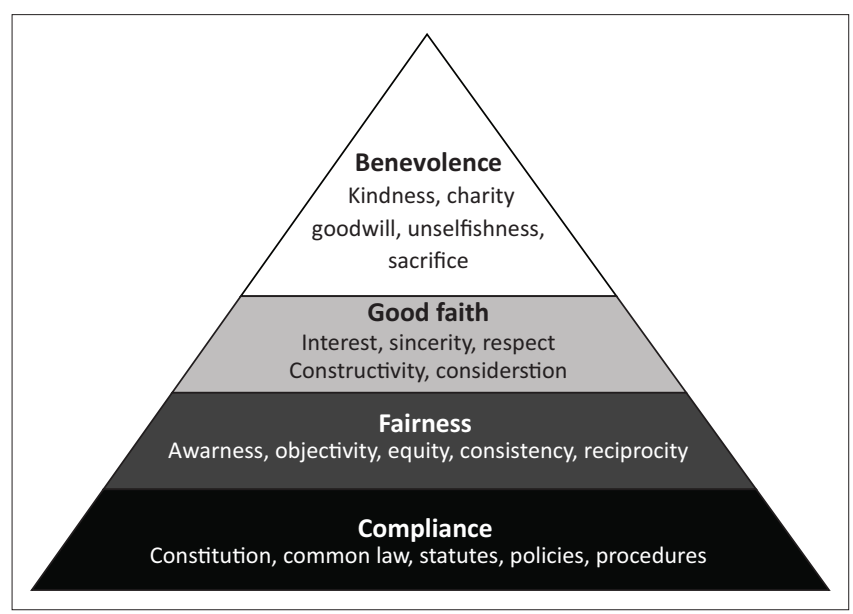

FIGURE 3: A theoretical hierarchy of employment relations trust.

\section{Employment relations trust as a theoretical hierarchy}

The development of ERT can also be explained by means of a theoretical hierarchy in which benevolence represent an elusive and erratic pinnacle. Figure 3 represents a theoretical hierarchy of ERT. The pattern of energy release in this hierarchy can be likened to the patterns of energy release in the Maslow hierarchy of needs. All descriptions that were listed under 4.3.1 and all boundary conditions that were described under 4.3.2 are applicable to the content of Figure 3.

\section{Limitations and recommendations}

This study was concluded after establishing related concepts and boundary conditions of a general theory on the development of ERT, as well as relationships between ERT and compliance, fairness, good faith and, in particular, benevolence in employment relations. However, the final stage in the theory validation process entails critical experimentation and hypothesis testing studies in larger samples. Expanded research instruments should be considered for this purpose.

The research measurement that was developed and applied in this study was more than adequately valid and reliable for purposes of this study. However, the development of an expanded measure of ERT should be seriously considered before undertaking further research into the validity of the theory that was developed in this study.

It can be confidently expected that employment relations distrust (ERD) will also develop through a few related stages that may be the opposite of ERT development stages (e.g. noncompliance, unfairness, bad faith and malevolence). Similar investigations can be conducted in accordance with the methodology that was adopted in this study. An appropriate research instrument should be developed for such studies.

The moral, ethical and spiritual dimensions of ERT were not considered or investigated in this study. Further research into these phenomena could contribute to a better understanding of the nature of trust in modern employment relations.

No specific conclusions or recommendations were made on the advent, size, duration and overlaps between the respective stages of ERT. Further investigations are thus needed.

Academics and managers perceived higher levels of fairness, good faith and benevolence at different ERT levels. Their perceptions may have been influenced by age, position or power variables. Further investigations in much larger research samples could yield more definite conclusions in these regards.

It seems as if ERT can also be explained in the context of vortex theory (Carrington, 2014) sap rings in large trees (Denny, 2011) or spiral theory (Matthes, 2015). Figure 4 suggests potential relationships between the development of ERT and the phenomena.

Despite the limitations, it can be confidently assumed that this study yielded adequately valid and reliable descriptions 


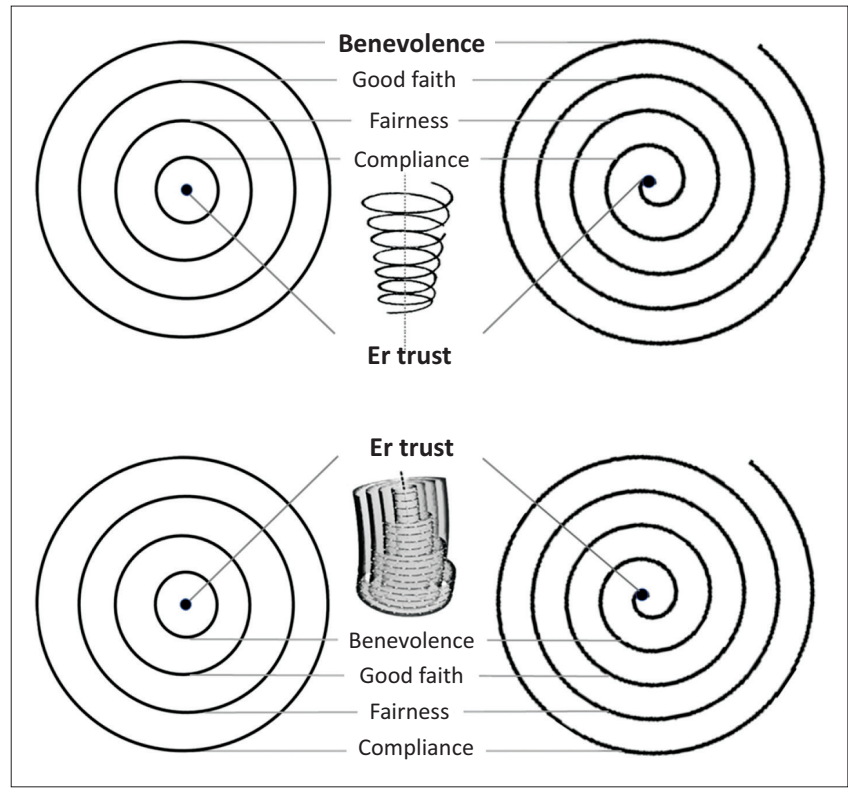

ERT, employment relations trust.

FIGURE 4: Employment relations trust development in vortex and spiral contexts.

of related phenomena and boundary conditions that would be required to establish a coherent theory of the development of ERT. It is therefore hoped that these findings can provide solid foundations for further related studies.

\section{Concluding remarks}

This article reported on a study that was undertaken to investigate and determine the stages through which ERT develops and the nature and role of benevolence in ERT development. The achievement of these objectives required that the validity of two hypotheses be tested. Findings from a literature review and statistical analysis of data were reviewed and integrated, and confident recommendations and conclusions were discussed under Section Integrated findings. Descriptions and boundary conditions of a theory of ERT were confidently recommended, and limitations of the study were described.

It can be concluded that ERB is the erratic pinnacle of a four levelled theoretical hierarchy of ERT. However, ERB may also occur before, during or after displays of compliance, fairness or good faith (see Figure 3). However, compliance, fairness and to a lesser extent good faith are typical legally protected employment rights and duties in free market economies, but benevolence is not. Employer and employee displays of compliance, fairness and good faith in free market-based employment relations are therefore mere displays of legally required reciprocal beneficence towards each other. Such displays should subsequently not be mistaken for intentional displays of kindness, charity, goodwill, unselfishness or sacrifice (ERB) towards employment relations partners. Furthermore, it should be noted that displays of noncompliance, unfairness or bad faith will typically reduce trust and discourage intentional displays of benevolence in employment relations. Nonetheless, ERB can be regarded as a desirable organisational phenomenon.
Many societies through the ages believed that human beings have the moral capacity to do unto others as they would do unto themselves. Such capacities could include appropriate displays of compliance, fairness, good faith, as well as benevolence in employment relations. Smith (1759) once wrote:

$[H]$ ow selfish soever man may be supposed, there are evidently some principles in his nature, which interest him in the fortune of others, and render their happiness necessary to him, though he derives nothing from it, except the pleasure of seeing it.

In stark contrast, Smith (1776) later wrote that 'It is not from the benevolence of the butcher, the brewer, or the baker that we expect our dinner, but from their regard to their own selfinterest $t^{\prime}$. This statement is one on the revered mainstays of free market thinking in modern societies, and it is thus not likely that benevolence will become a legal requirement in free market economies or employment relations any time soon.

Nonetheless, the findings of this study confirm that intentional displays of humane reciprocity in all dimensions of employment relations are desirable organisational phenomena that are worth encouraging in all forms of employment relations. Displays of compliance, fairness, good faith and benevolence can facilitate a wide range of desirable outcomes for all stakeholders in employment relations. It is hoped that the results of this study will provide a better understanding of the role and nature of benevolence in free market-based employment relations.

\section{Acknowledgements Competing interests}

The author has declared that no competing interests exist.

\section{Author's contributions}

L.I.E. is the sole author of this research article.

\section{Ethical considerations}

This article followed all ethical standards for a research without direct contact with human or animal subjects.

\section{Funding information}

The research received no specific grant from any funding agency in the public, commercial or not-for-profit sectors.

\section{Data availability}

Data sharing is not applicable to this article as no new data were created or analysed in this study.

\section{Disclaimer}

The views and opinions expressed in this article are those of the author and do not necessarily reflect the official policy or position of any affiliated agency or authors. 


\section{References}

Beauchamp, T. (2016). The principle of beneficence in applied ethics. In E.N. Zalta (Ed.), The Stanford Encyclopaedia of philosophy (Winter 2016 ed.). Retrieved from https://plato.stanford.edu/archives/win2016/entries/principle-beneficence/

Bell, C.M., \& McKague, K. (2009). Fairness, uncertainty, trust, and benevolence. In C. Moliner (Ed.), Organizational justice: International perspectives and conceptual advances (pp. 81-204). Oxford: Routledge.

Cappelletti, L., Khalla, S., Noguera, F., Scouarnec, A., \& Voynnet Fourboul, C. (2010) Toward a new trend of managing people through benevolence? Management \& Avenir, 36(6), 263-283. https://doi.org/10.3917/mav.036.0263

Carrington, A.M. (2014). The vortex of violence: Moving beyond the cycle and engaging clients in change. The British Journal of Social Work, 44(2), 451-468. https://doi.org/10.1093/bjsw/bcs116

Covey, S. (2006). The speed of trust. The one thing that changes everything. London: Simon \& Schuster.

Cozby, P., \& Bates, S. (2015). Methods in behavioural research (12th ed.). New York, NY: McGraw-Hill Education.

Cresswell, J.W. (2014). Research design: Qualitative, quantitative and mixed-methods approaches (4th ed.). London: Sage.

Dalai Lama. (2011). The art of happiness in a troubled world. Sydney: Hachette Australia.

Darwin, C. (1859). On the origin of species. London: Murray

Denny, M. (2011). Tree hydraulics: How sap rises. European Journal of Physics, 33(1) 43. https://doi.org/10.1088/0143-0807/33/1/003

Desmet, P., \& Fokkinga, S. (2020). Beyond Maslow's pyramid: Introducing a typology of thirteen fundamental needs for human-centered design. $3390 / \mathrm{mti} 4030038$

Dietz, G., \& Hartog, D.N. (2015). Measuring trust inside organisations. Personne Review, 35(5), 557-588. https://doi.org/10.1108/00483480610682299

DiMatteo, L.A., Bird, R.C., \& Colquitt, J.A. (2011). Justice, labour, and the psychological contract, selected works. University of Florida. Retrieved from http://works. bepress.com/larry_dimatteo/6

Ehlers, L.I. (2020). Trust and perceptions of compliance, fairness and good faith in primary labour relationships. South African Journal of Economic and Management Sciences, 23(1), a3353. https://doi.org/10.4102/sajems.v23i1.3353

Einstein, A. 1935. The world as I see it (Translated from the German by A. Harris) London: John Lane, The Bodley Head.

Fawcett, S.E., Fawcett, A.M., \& Jin, Y.H. (2017). I know it when I see it: The nature of trust, trustworthiness signals, and strategic trust construction. The International Journal of Logistics Management, 28(4), 914-938. https://doi.org/10.1108/IJLM11-2016-0268

Firmansyah, M.R., Amalia, R., Faturochman, F., \& Minza, W.M. (2019). Benevolence competency, and integrity: Which one is more influential on trust in friendships?

Gay, B., \& Weaver, S. (2011). Theory building and paradigms: A primer on the nuances of theory construction. American International Journal of Contemporary Research, 1(2), 24-32.

Ghatak, S., \& Singh, S. (2019). Examining Maslow's hierarchy need theory in the social media adoption. FIlB Business Review, 8(4), 292-302. https://dol. org/10.1177/2319714519882830

Hubbard, J., Harbaugh, W.T., Srivasta, S., Degras, D., \& Mayr, U. (2016). General benevolence dimension that links neural, psychological, economic, and life-span data on altruistic tendencies. Journal of Experimental Psychology, 145(10), 13511358. https://doi.org/10.1037/xge0000209

International Labour Organisation (ILO). (2020). Safe and healthy working environments free from violence and harassment. Geneva: ILO Publications.

Kant, I. (1785). Grounding for the metaphysics of morals (third edition) with on a supposed right to lie because of philanthropic concerns. Translated by James W. supposed right to lie because of philanthropic concerns. Translated
Ellington (1993- 92 p.). Indianapolis: Hackett Publishing Company.

Krot, K., \& Lewicka, D. (2012). The importance of trust in manager-employee relationships. International Journal of Electronic Business Management, 10(3), 224-233.

Kushitor, M.K., Peterson, M.B., Asante, P.Y., Dodoo, N.D., Boatemaa, S., \& Awuah, R.B. (2018). Community and individual sense of trust and psychological distress among the urban poor in Accra, Ghana. PLoS One, 13(9), 1-13. https://doi.org/10.1371/ journal.pone.0202818

Law, M. (2013). Exploring forgiveness: Do benevolence and revenge associate with procedural justice, workplace satisfaction and intention to leave? Internationa Journal of Management Sciences and Business Research, 2(12), 167-179.

Maslow, A.H. (1943). A theory of human motivation. Psychological Review, 50(4), 370-396. https://doi.org/10.1037/h0054346

Maslow, A.H. (1971). The farther reaches of human nature. New York, NY: Viking Press.

Matthes, J. (2015). Observing the 'spiral' in the spiral of silence. International Journal of Public Opinion Research, 27(2), 155-176. https://doi.org/10.1093/ijpor/ edu032

Mayer, R.C., Schoorman, F.D., \& Davis, J.H. (2007). An integrative model of organizational trust: Past, present, and future. Academy of Management Review, 32(2), 344-354. https://doi.org/10.5465/amr.2007.24348410
Mbuma, A. (2019). The role of perceived compliance, fairness and good faith in the establishment of trust in primary labour relationships. Unpublished Masters dissertation. Pretoria: Tshwane University of Technology.

McKnight, H., \& Chervany, N.L. (2014). Trust and distrust definitions: One bite at a time. Retrieved from https://www.researchgate.net/publication/220793934

Ogunyemi, K. (2014). Justice, care and benevolence as spurs to employee loyalty. International Journal of Academic Research in Management, 3(2), 110-125.

Priesemuth, M. (2020). Time's up for toxic workplaces. Harvard Business Review. Retrieved from https://hbr.org/2020/06/times-up-for-toxic-workplaces

Rakhshani, Z. (2017). The golden rule and its consequences: A practical and effective solution for world peace. Journal of History Culture and Art Research, 6(1) 465-473. https://doi.org/10.7596/taksad.v6i1.754

Robbins, S., Judge, T., \& Campbell, T. (2017). Organizational behaviour (2nd edn.). Boston: Pearson.

Salkind, N.J. (2014). Statistics for people who think they hate statistics (5th ed.). Los Angeles, CA: Sage.

Sarkar, A. (2017). Leadership role in instilling workplace spirituality in organizations. Purshartha, 10(2), 61-68. https://doi.org/10.21844/pajmes.v10i02.10570

Savolainen, T.I., \& Ikonen, M. (2016). Process dynamics of trust development: Exploring and illustrating emergence in the team context. In S. Jagd (Ed.), Trust, organizations and social interaction: Studying trust as process within and between organizations (pp. 231-256). Cheltenham: Edward Elgar.

Schilke, O., \& Cook, K.S. (2013). A cross-level process theory of trust development in interorganizational relationships. Strategic Organization, 11(3), 281-303. https:// doi.org/10.1177/1476127012472096

Schweitzer, A. (1987). Civilization and ethics. In The philosophy of civilization translated by C.T. Campion. Amherst, NY: Prometheus Books.

Searle, R.H., \& Skinner, D. (2011). Trust and human resource management Cheltenham: Edward Elgar.

Shanock, L.R., \& Eisenberger, R. (2006). When supervisors feel supported Relationships with subordinates, perceived supervisor support, perceived organizational support, and performance. Journal of Applied Psychology, 91(3), 689-695. https://doi.org/10.1037/0021-9010.91.3.689

Simoncelli, D. (2020). From natural law to the golden rule: Aquinas revisited. Ethics, Politics \& Society, 1(1), 15. https://doi.org/10.21814/eps.1.1.58

Smith, A. (1759). The theory of moral sentiments. London: Printed for A. Millar, and A Kincaid and J. Bell.

Smith, A. (1776). The wealth of nations. London: W. Strahan \& T. Cadell.

Smuts, J.C. (1926). Holism and evolution. London: Macmillan.

Snow, C.C., \& Thomas, J.B. (1994). Field research methods in strategic management: Contributions to theory building and testing. Journal of Management Studies, 31(4), 457-480. https://doi.org/10.1111/j.1467-6486. 1994.tb00626.x

Sree, D.V., \& Gunaseelan, R. (2018). A study on mediating effect of altruistic behavior on benevolent leadership and psychological well-being. Arabian Journal of Business and Management Review, 8(4), 1-7.

Starnes, B.J., Truhon, S.A., \& McCarthy, V. (2016). Organisational trust: Employee employer relationships. Retrieved from https://asq.org/hdl/2010/06/a-primeron-organizational-trust.pdf

Stern, M.J., \& Coleman, K.J. (2015). The multidimensionality of trust: Applications in collaborative natural resource management. Society \& Natural Resources, 28(2), 117-132. https://doi.org/10.1080/08941920.2014.945062

Tallant, J., \& Donati, D. (2020). Trust: from the Philosophical to the Commervial. Philosophy of Management, 19, 3-19.

Thomsen, L. (2020). The developmental origins of social hierarchy: How infants and young children mentally represent and respond to power and status. Current Opinion in Psychology, 33(June), 201-208. https://doi.org/10.1016/j.copsyc.2019. 07.044

Trotsuk, I. (2016). "To trust or not to trust" is not the question; "How to study trust" is much more challenging task'. Russian Sociological Review, 15(4), 57-75. https:// doi.org/10.17323/1728-192X-2016-4-57-75

Tullberg, J. (2012). The golden rule of benevolence versus, the silver rule of reciprocity. Journal of Religion and Business Ethics, 3, Article 2. Retrieved from https://via. library.depaul.edu/jrbe/vol3/iss1/2

Viviers, D., \& Smit, D.M. (2014). A labour law perspective on the protection of persons in a vulnerable employment relationship in South Africa. International Journal of Business and Social Research, 4(5), 59-71.

Wu, J. (2013). Hierarchy theory: An overview in linking ecology and ethics for a changing world: Values, philosophy, and action. In R. Rozzi (Ed.). Linking ecology and ethics for a changing world (pp. 281-301). Dordrecht: Springer.

Xin Tan, J., \& Dahlia, Z. (2016). Benevolent leadership and its organisational outcomes: A social exchange theory perspective. International Journal of Economics and Management, 10(2), 343-364.

Zapata, C.P., Olsen, J.E., \& Martins L.L. (2013). Social exchange from the supervisor's perspective: Employee trustworthiness as a predictor of interpersonal and informational justice. Organizational Behavior and Human Decision Processes, 121(1), 1-12. https://doi.org/10.1016/j.obhdp.2012.11.001 